Article

\title{
Titanium Dioxide Grafted on Graphene Oxide: Hybrid Nanofiller for Effective and Low-Cost Proton Exchange Membranes
}

\author{
Cataldo Simari ${ }^{1}{ }^{1}$, Ernestino Lufrano ${ }^{1}$, Nicolas Godbert ${ }^{1}\left(\right.$, Dimitrios Gournis ${ }^{2}$, \\ Luigi Coppola ${ }^{1}$ and Isabella Nicotera ${ }^{1, * \mathbb{D}}$ \\ 1 Department of Chemistry and Chemical Technologies, University of Calabria, 87036 Rende (CS), Italy; \\ cataldo.simari@unical.it (C.S.); ernestino.lufrano@unical.it (E.L.); nicolas.godbert@unical.it (N.G.); \\ lg.coppola@unical.it (L.C.) \\ 2 Department of Material Science and Engineering, University of Ioannina, 45110 Ioannina, Greece; \\ dgourni@cc.uoi.gr \\ * Correspondence: isabella.nicotera@unical.it; Tel.: +39-098-4493379
}

Received: 7 July 2020; Accepted: 9 August 2020; Published: 10 August 2020

\begin{abstract}
A nanostructured hybrid material consisting of $\mathrm{TiO}_{2}$ nanoparticles grown and stabilized on graphene oxide (GO) platelets, was synthesized and tested as nanofiller in a polymeric matrix of sulfonated polysulfone (sPSU) for the preparation of new and low-cost nanocomposite electrolytes for proton exchange membrane fuel cell (PEMFC) applications. GO- $\mathrm{TiO}_{2}$ hybrid material combines the nanoscale structure, large interfacial area, and mechanical features of a 2D, layered material, and the hygroscopicity properties of ceramic oxides, able to maintain a suitable hydration of the membrane under harsh fuel cell operative conditions. $\mathrm{GO}_{-} \mathrm{TiO}_{2}$ was synthetized through a new, simple, one-pot hydrothermal procedure, while nanocomposite membranes were prepared by casting using different filler loadings. Both material and membranes were investigated by a combination of XRD, Raman, FTIR, thermo-mechanical analysis (TGA and Dynamic Mechanical Analysis) and SEM microscopy, while extensive studies on the proton transport properties were carried out by Electrochemical Impedance Spectroscopy (EIS) measurements and pulse field gradient (PFG) NMR spectroscopy. The addition of GO-TiO 2 to the sPSU produced a highly stable network, with an increasing of the storage modulus three-fold higher than the filler-free sPSU membrane. Moreover, the composite membrane with $3 \mathrm{wt}$.\% of filler content demonstrated very high water-retention capacity at high temperatures as well as a remarkable proton mobility, especially in very low relative humidity conditions, marking a step ahead of the state of the art in PEMs. This suggests that an architecture between polymer and filler was created with interconnected routes for an efficient proton transport.
\end{abstract}

Keywords: graphene oxide; nanocomposite membranes; PEMFCs; proton transport; sulfonated polysulfone

\section{Introduction}

Proton exchange membrane fuel cells (PEMFCs) are recognized worldwide as one of the most promising clean energy conversion technologies [1,2]. Owing to their high chemical-to-electrical energy conversion efficiency, and due to their zero- $\mathrm{CO}_{2}$ emission (when $\mathrm{H}_{2}$ is used as fuel), PEMFCs are targeted as an energy source for electric vehicles, although they are also proposed for a wide range of applications, from portable to automotive and stationary. However, there are still several issues to be addressed for a large scale-up of this technology. Most of them are related to the intrinsic properties of the electrolyte membrane (proton exchange membrane-PEM), in particular its ability to maintain adequate proton conductivity even under drastic operating conditions, i.e., 
working temperatures above $100{ }^{\circ} \mathrm{C}$ (from the current $70-90{ }^{\circ} \mathrm{C}$ ) and low humidification. Indeed, increasing the temperature (the DOE, Department of Energy USA, fixed the temperature target at $120{ }^{\circ} \mathrm{C}$ ), the cell performance improves because (1) higher electrode reaction rates take place, (2) simplified and more effective water management in the cell occurs, (3) enhanced CO tolerance by the electrocatalyst $(\mathrm{Pt})$ is induced, and (4) faster heat rejection rates and better systems integration are observed [3]. The state-of-the-art PEM is based on Nafion ${ }^{\circledR}$, a perfluorosulfonic acid ionomer (PFSA), developed in the 1960s by Dupont, which is still, nowadays, the most used membrane both in fuel cell research and industry, since it combines high proton conductivity, excellent chemical stability, and good mechanical resistance. However, under the operative conditions of high temperature and low humidification (required in several applications such as automotive), Nafion membranes easily loose water, so that the proton conductivity decreases of several orders of magnitude with respect to the fully hydrated membrane. Furthermore, its high environmental impact, due to its content in fluorine atoms, and its elevated production costs are both issues that are driving the research toward alternative proton conductive ionomers [4]. In this regard, great efforts have been devoted to the development of non-fluorinated polymers (n-FPs) [5]. A large variety of aromatic thermoplastics ionomers, such as sulfonated polyether ether ketone [6,7], sulfonated polyphenylsulfone [8], phosphoric acid doped polybenzimidazole [9,10], sulfonated polyether sulfone [11-13], sulfonated polysulfone [14,15], and sulfonated polyimides [16], is being actively investigated, showing high thermo-oxidative, chemical, and mechanical stabilities. Additionally, several approaches have been developed to improve the performance of n-FPs, including the modification of the ionomer backbone with specific functional groups, the production of polymer blends and the preparation of composites' membranes by introduction of proper hygroscopic nanoadditives [17,18]. Accordingly, most of the attention has been directed toward the preparation of organic-inorganic composite membranes because they offer the possibility to effectively combine both the thermo-mechanical stability of the polymer backbone and the chemical reactivity of the filler [19]. For instance, the incorporation of $\mathrm{SiO}_{2}, \mathrm{ZrO}_{2}, \mathrm{TiO}_{2}$, zeolites, zirconium hydrogen phosphonates, and Layered Doubled Hydroxide (LDH) materials has been demonstrated to remarkably improve the physico-chemical and mechanical properties of the resulting composite membranes, as well as the electrochemical behavior since the high acid surface area and hydrophilicity of such nanofillers usually favor the proton transport [20-23].

Among the nanostructured materials, graphene oxide (GO), produced by oxidation of graphite, has been considered attractive for many applications owing to its fascinating physical and chemical features [24]. While still preserving the typical layered structure of the parent graphite, which provides a large surface area, GO exhibits also electronic insulating property, high dispersive capacity, and remarkable proton conduction features [25]. These features endow GO with great potential as a nanofiller in PEMs for PEMFCs applications. Indeed, GO has been successfully incorporated into Nafion, either alone or coupled with other active components with the main objective to boost proton transport [26-28]. However, in order to really be efficient, proper surface chemical functionalization must be performed to enhance the number of acid/hydrophilic groups, thus providing additional continuous pathways for facile proton transport [29]. In fact, it has been largely reported that the incorporation of sulfonated graphene oxide remarkably improves the transport and mechanical features of Nafion, sulfonated polyimide, and polybenzimidazole [30-32]. Similar outcomes were also exhibited after introduction of both phosphorylated graphene oxide [33] and polydopamine-modified GO [34] nanofillers.

In this work, a hybrid nanoadditive, which combines the proton conduction characteristic of $\mathrm{GO}$ with the water-holding ability of inorganic oxides, such as $\mathrm{TiO}_{2}$, was proposed. Titanium oxide nanoparticles are high surface area hygroscopic ceramic oxides, which demonstrate good compatibility with organic solvents and polymers as well as displaying good hydrophilicity, mechanical, and thermal stabilities [35]. However, in the preparation of composite membranes, one of the most important and challenging aspects is to obtain an effective nanodispersion of the filler within the polymeric matrix, avoiding the formation of micrometric agglomerates, usually observed with ceramic oxides' 
nanoparticles [36]. Therefore, in this work, titania nanoparticles were dispersed and stabilized on graphene platelets by chemical grafting in order to allow homogeneous dispersion and create a nanoadditive able to maintain high proton conductivity even under elevated-temperature and low-humidity conditions.

To this purpose, titania-decorated graphene oxide $\left(\mathrm{GO}-\mathrm{TiO}_{2}\right)$ was successfully synthesized via a one-pot thermal hydrolysis of titanium(IV) butoxide used as $\mathrm{TiO}_{2}$ precursor in a GO highly dispersed suspension.

Usually, graphene/ $\mathrm{TiO}_{2}$ nanomaterials are synthesized under extreme or special conditions, i.e., high-pressure atmosphere [37], high temperature in autoclave [38], or UV irradiation [39]. Although successful, these methods are probably not commercially viable since they often require multistep or expensive processes. Herein, we report a simple one-pot hydrothermal procedure, conducted at intermediate temperature $\left(60^{\circ} \mathrm{C}\right)$. This makes our procedure more attractive and suitable to industrial-scale process.

Subsequently, GO- $\mathrm{TiO}_{2}$ nanohybrid was dispersed in sulfonated polysulfone (sPSU) for the preparation of low-cost and more eco-friendly proton exchange membrane with respect to the more commonly studied and used Nafion. Polysulfone was selected as a polymeric matrix due to its numerous interesting characteristics ranging from low cost, large availability, low environmental impact, and good film-forming capacity, to its considerable thermo-mechanical strength. For applications in PEMFCs, the transport and structural features of polysulfone can be easily tuned through the degree of sulfonate groups introduced, which can be controlled by choosing the sulfonation procedure. In this report, the sPSU was successfully synthesized according to the procedure proposed by Lufrano et al., which involves the use of trimethylsilylchlorosulfonate as sulfonating agent and allowed us to suitably and easily calibrate degree of sulfonation through reaction times $[15,40]$. The final product had an ion exchange capacity (IEC) of $1.36 \mathrm{meq}^{-1}$, selected as the compromise value between the structural stability of the macromolecule and the appropriate proton transport properties.

The sPSU_GO- $\mathrm{TiO}_{2}$ nanocomposite membranes, at various additive loadings, were prepared by the solution-casting procedure adequately tuned to ensure a homogeneous dispersion. As of now, to our best knowledge, $\mathrm{GO}-\mathrm{TiO}_{2}$ hybrid material has not been investigated in nanocomposite electrolytes for PEMFC applications. Both the hybrid nanofiller and nanocomposite membranes were characterized by a combination of powder X-ray diffraction (XRD), Raman and Fourier-transform infrared (FTIR) spectroscopies, and thermogravimetric analysis (TGA). The morphological features were investigated by scanning electron microscopy, while the mechanical properties of the membranes were tested by dynamic mechanical analysis (DMA) in a wide temperature range. A thorough investigation of the proton transport properties and of water molecular dynamics inside the hydrophilic clusters of the nanocomposite membranes was conducted by the pulse field gradient (PFG) NMR spectroscopy. Finally, ac impedance spectroscopy was carried out to clarify the influence of the GO-TiO 2 nanohybrid on both the proton conductivity and hydrolytic stability of the resulting PEMs.

\section{Materials and Methods}

\subsection{Materials and Chemicals}

Graphite powder (powder $<20 \mathrm{~mm}$ ), sulfuric acid (95-97 wt.\%), nitric acid (65 wt.\%), potassium chlorate powder (purum, $>98.0 \%$ ), titanium(IV) butoxide (reagent grade, 97\%), isopropyl alcohol (ACS reagent, $\geq 99.5 \%$ ) and N,N-dimethylacetamide (anhydrous, 99.8\%) were all purchased from Sigma-Aldrich and used as received. The sPSU with ion exchange capacity of $1.36 \mathrm{meq} \mathrm{g}^{-1}$ was synthesized as reported elsewhere [15].

\subsection{Synthesis of Graphene Oxide}

Graphene oxide (GO) was prepared according to the following procedure [41,42]: $10 \mathrm{~g}$ of graphite powder and $200 \mathrm{~g}$ of potassium chlorate powder were slowly added to a mixture of sulfuric acid 
and nitric acid (400:200 mL, respectively). The reaction was conducted in an ice bath under vigorous magnetic stirring for $18 \mathrm{~h}$ and thus quenched by pouring the mixture into distilled water. The final GO product was centrifuged, washed several times with distilled water until the $\mathrm{pH}=6.0$, and was finally dried at room temperature.

\subsection{Functionalization of $\mathrm{GO}$ with $\mathrm{TiO}_{2}\left(\mathrm{GO}-\mathrm{TiO}_{2}\right)$}

GO- $\mathrm{TiO}_{2}$ was synthesized via thermal hydrolysis of titanium(IV) butoxide in a GO suspension, as illustrated in Scheme 1. In a two-neck, round-bottom flask, titanium(IV) butoxide was added to a mixture of water, isopropyl alcohol, and nitric acid. The solution was heated to $60{ }^{\circ} \mathrm{C}$ in an oil bath and stirred for $1 \mathrm{~h}$ to produce a Titanium(IV) ionic $\left(\mathrm{Ti}^{4+}\right)$ solution. Subsequetly, a homogenous aqueous dispersion of exfoliated GO was slowly added dropwise and the resulting mixture was stirred at $60{ }^{\circ} \mathrm{C}$ for $18 \mathrm{~h}$. The titanium butoxide/GO mass ratio was 14:1. The dispersion was then centrifuged at 15,000 $\mathrm{r} \mathrm{min}^{-1}$ (ca. 26,000 g) for $10 \mathrm{~min}$ and the deposited solid was repeatedly washed with deionized water and ethanol. Finally, the $\mathrm{GO}-\mathrm{TiO}_{2}$ sample was vacuum-dried at $60{ }^{\circ} \mathrm{C}$ overnight prior to characterization. The $\mathrm{GO}-\mathrm{TiO}_{2}$ nanohybrid material was obtained as a black, fine powder.

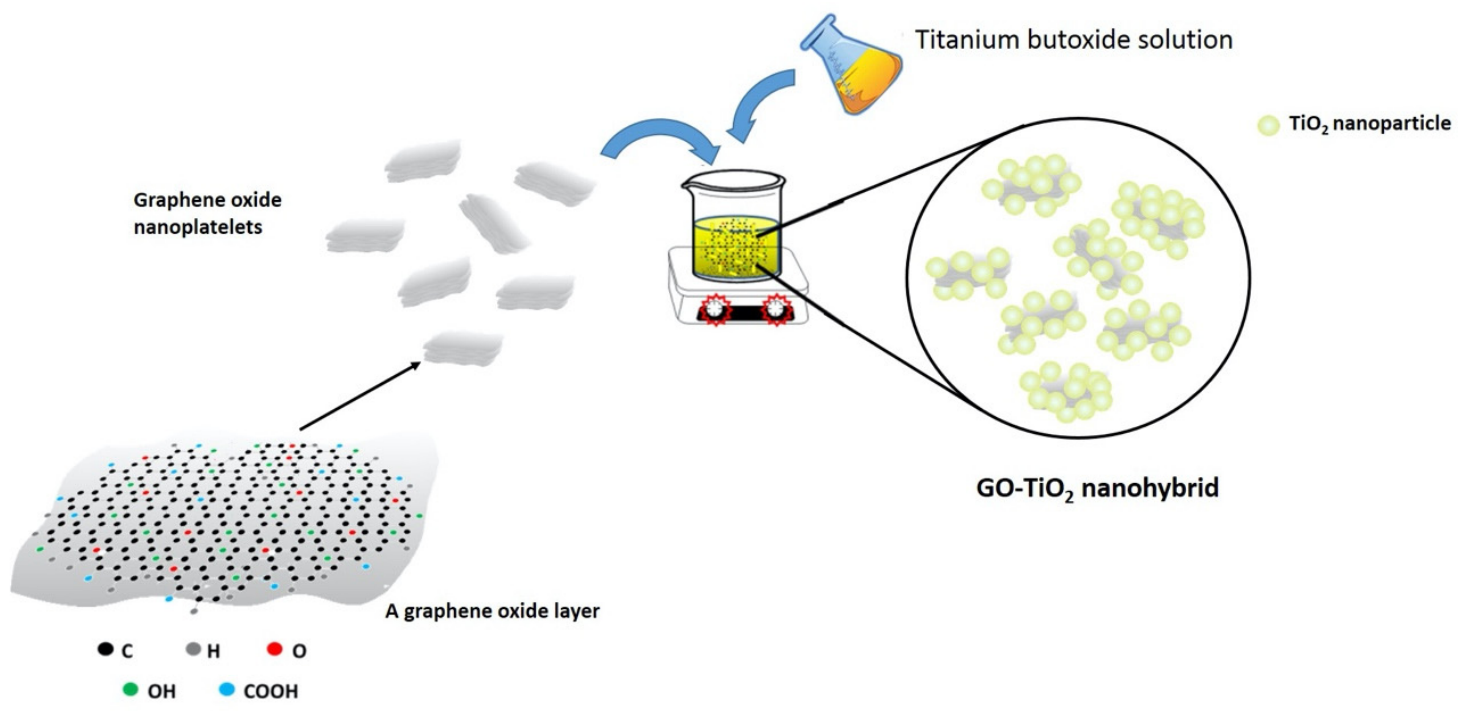

Scheme 1. Synthesis route of the $\mathrm{GO}-\mathrm{TiO}_{2}$ nanohybrid material.

\subsection{Preparation of the Nanocomposite Membranes}

The sPSU-based composite membranes at three different filler loadings, i.e., containing 2, 3, and 5 wt.\% of $\mathrm{GO}^{-\mathrm{TiO}_{2}}$, were prepared by solution-casting procedure. Typically, $150 \mathrm{mg}$ of sPSU were dissolved in $10 \mathrm{~mL}$ of $\mathrm{N}, \mathrm{N}$-dimethylacetamide at room temperature to form a clear solution. Then, the appropriate amount of the $\mathrm{GO}^{-\mathrm{TiO}_{2}}$ nanohybrid was directly added in the sPSU-DMAc polymer solution, ultrasonicated for 1 day, and stirred for another day at room temperature until a macroscopically homogeneous dispersion was obtained. The mixture was cast on a petri dish at $80{ }^{\circ} \mathrm{C}$ and left to dry. A pure sPSU membrane was also prepared through identical procedure. Before any characterization, all membranes were pretreated by immersing in $1 \mathrm{M} \mathrm{H}_{2} \mathrm{SO}_{4}$ solution at $60{ }^{\circ} \mathrm{C}$ for $15 \mathrm{~h}$ and finally rinsed in deionized water to remove any residual trace of acid. The dry thickness of the membranes was $40 \pm 10 \mu \mathrm{m}$.

\subsection{Characterization of $\mathrm{GO}, \mathrm{GO}-\mathrm{TiO}_{2}$, and Composite Membranes}

X-ray diffraction (XRD) measurements were performed using the $\mathrm{Cu}-\mathrm{K} \alpha$ radiation of a Bruker AXS Diffractometer/Reflectometer (D8) (Bruker, Karlsruhe, Germany) equipped with a Dynamic Scintillation Detector, NaI, and with a Gobel mirror. The experimental tests were made in transmission, and the powder samples carefully were put in glass capillaries $(\phi=1 \mathrm{~mm}$, Hilgen-berg GmbH, Karlsruhe, 
Germany) and then a sample holder [43]. Spectra were collected at room temperature in the $2 \theta$ range from $5^{\circ}$ to $40^{\circ}$, in steps of $0.03^{\circ}$ and the counting time was $1 \mathrm{~s} / \mathrm{step}$.

The FTIR spectra were recorded in the range of $400-3600 \mathrm{~cm}^{-1}$ using a Perkin-Elmer Spectrum GX instrument with $\mathrm{KBr}$ pellets. Each spectrum was the average of 64 scans collected at $2 \mathrm{~cm}^{-1}$ resolution, and these were averaged to improve the signal-to-noise-ratio.

The Raman spectra were recorded with a Jobin Yvon micro-Raman LABRAM apparatus (HORIBA Ltd., Kyoto, Japan). The 632.8-nm wavelength of a He-Ne laser was used as an excitation source. An objective 50× Olympus lens with a focal length of $15 \mathrm{~mm}$ was used. The resulting power was about $5 \mathrm{~mW}$, focused on a spot of about $5 \mu \mathrm{m}$ of diameter. The interaction at molecular levels of the organo-modified derivatives can be investigated by studying the changes of Raman spectra. To have a complete view of such phenomena, the Raman spectra were collected in the range of 200 to $3900 \mathrm{~cm}^{-1}$.

Thermogravimetric analyses (TGA) were carried out in a TG-7 instrument from Perkin-Elmer. The samples were heated from 50 to $900{ }^{\circ} \mathrm{C}$ under flowing nitrogen, at a heating rate of $10^{\circ} \mathrm{C} \mathrm{min}-1$. Prior to the measurements, samples were dried in an oven at $60^{\circ} \mathrm{C}$ for $24 \mathrm{~h}$.

SEM morphologic images and energy dispersive X-ray spectroscopy (EDX) were acquired on a Phenom ProX scanning electron microscope (Thermo Fisher Scientific Inc., Waltham, MA, USA) equipped with a backscattered electron detector. Samples were placed on carbon-conductive, double-coated tabs and were observed and analyzed without coating. Membranes' sections were performed on samples that were cut under freezing condition after immersion in a nitrogen liquid bath.

Conventional titration method was used in this work to determine the ion exchange capacity (IEC in milliequivalents per $g$ of dry polymer) of the functionalized sPSU-based membranes [12]. The procedure was determined by potentiometric acid-base titration. After the exchange with $\mathrm{H}^{+}$ ions, the membranes were washed in deionized water and dried over $\mathrm{P}_{2} \mathrm{O}_{5}$ for $24 \mathrm{~h}$. Subsequently the samples were weighed $\left(W_{d r y}\right)$ and immersed in a solution of $0.5 \mathrm{M} \mathrm{NaCl}$ solution for $48 \mathrm{~h}$ at $60^{\circ} \mathrm{C}$. The resulting solution was then back-titrated with a solution of $\mathrm{NaOH} 0.1 \mathrm{M}$ using phenolphthalein as an indicator. The IEC value is calculated by the following Equation (1).

$$
I E C=\frac{V_{\mathrm{NaOH}} \times \mathrm{C}_{\mathrm{NaOH}}}{W_{d r y}} ;\left[\mathrm{meq} \mathrm{g}^{-1}\right]
$$

Water uptake was measured by immersing the dried membranes $\left(W_{d r y}\right)$ in deionized water at room temperature for $24 \mathrm{~h}$. The membrane was then quickly dried with tissue paper to remove surface water droplets and weighed $\left(W_{\text {wet }}\right)$. The water uptake was calculated by Equation (2) and reported as an average of three independent measurements.

$$
w . u=\frac{W_{\text {wet }}-W_{d r y}}{W_{d r y}} \times 100 ;[\%]
$$

NMR measurements were performed on a Bruker AVANCE 300 wide-bore spectrometer working at $300 \mathrm{MHz}$ on ${ }^{1} \mathrm{H}$ with a Diff30 Z-diffusion $30 \mathrm{G} / \mathrm{cm} / \mathrm{A}$ multinuclear probe with substitutable RF inserts. The self-diffusion coefficients $(D)$ of water confined in the membranes have were measured by pulsed field gradient stimulated-echo (PFG-STE) sequence [44], by using the following experimental parameters: Pulse gradient length $(\delta) 1 \mathrm{~ms}$, diffusion delay time $(\Delta) 10 \mathrm{~ms}$, and the gradient amplitude $(g)$ varied from 100 to $900 \mathrm{G} / \mathrm{cm}$. The number of scans was 8 . Based on the very low standard deviation of the fitting curve and repeatability of the measurements, the uncertainties in D values were calculated to be circa 3\%. The NMR samples were prepared according to the procedure reported elsewhere [45] and the measurements were conducted by increasing the temperature from $20^{\circ} \mathrm{C}$ to $130{ }^{\circ} \mathrm{C}$, every $20^{\circ} \mathrm{C}$, by equilibrating the sample for about $15 \mathrm{~min}$ at each temperature.

Dynamic mechanical analysis (DMA) was conducted by Metravib DMA/25 analyzer equipped with a shear jaw for films' clamping. A dynamic stress of amplitude $10^{-4}$ at $1 \mathrm{~Hz}$ was applied on a rectangular-shaped sample, in the temperature range $25-180^{\circ} \mathrm{C}$, with a heating rate of $2^{\circ} \mathrm{C} \mathrm{min}^{-1}$. 
Proton conductivity $(\sigma)$ was measured by a homemade, two-electrodes cell in a through-plane configuration. A circular-shaped membrane was sandwiched between two sheets of conductive carbon papers and placed between two graphite-blocking electrodes. The cell was placed between the anode and cathode flow field of a fuel cell test hardware (850C, Scribner Associates Inc., Southern Pines, North Carolina, NC, USA). The AC impedance response of the cell was recorded using a PGSTAT 30 potentiostat/galvanostat (Methrom Autolab, Utrecht, Netherlands) equipped with a Frequency Response Analyser (FRA) module. Voltage amplitude was $10 \mathrm{mV}$ and the frequency range was $1 \mathrm{~Hz}-1 \mathrm{MHz}$. The obtained impedance data were analyzed by Metrohm Autolab NOVA software and the electrolyte resistance $\left(\mathrm{R}_{\mathrm{el}}\right)$ was determined from the high-frequency intersection with the real axis in Nyquist plot. Measurements were performed in the temperature range from $20^{\circ} \mathrm{C}$ up to $130{ }^{\circ} \mathrm{C}$ at the relative humidity $(\mathrm{RH})$ of $90 \%$. Proton conductivity $(\sigma)$ of the electrolyte membrane was calculated according to Equation (3).

$$
\sigma=\frac{L}{A \times R_{e l}} ;\left[\mathrm{S} \mathrm{cm}^{-1}\right]
$$

where $L$ is the distance between the electrodes, $R$ is the resistance, and $A$ is the active area.

Finally, the hydrolytic stability of the membranes was assessed in terms of relative variation of $\sigma$ during long-time operation. The membranes were kept at $80{ }^{\circ} \mathrm{C}$ under $100 \% \mathrm{RH}$ and the proton conductivity was measured at each interval of time $\left(\sigma_{t}\right)$ for $140 \mathrm{~h}$. For each measurement, the relative variation in proton conductivity $\left(\mathrm{Rv}_{\sigma}\right)$ was calculated according to Equation (4):

$$
\mathrm{Rv}_{\sigma}=\left(1-\frac{\sigma_{0}-\sigma_{t}}{\sigma_{0}}\right) \times 100 ;[\%]
$$

where $\sigma_{0}$ is the initial proton conductivity.

\section{Results and Discussion}

\subsection{Graphene Oxide (GO) and $\mathrm{GO}-\mathrm{TiO}_{2}$ Hybrid Nanomaterial}

XRD patterns of graphite, $\mathrm{GO}$, and $\mathrm{GO}-\mathrm{TiO}_{2}$ materials are shown in Figure 1. Pristine graphite exhibited a characteristic diffraction peak at $2 \theta$ of $26.3^{\circ}$, corresponding to a basal $\mathrm{d}_{002}=0.34 \mathrm{~nm}$ [46]. Graphene oxide, instead, showed a strong basal reflection peak at $12.0^{\circ}$ with a $\mathrm{d}_{001}=0.73 \mathrm{~nm}$. Such increasing of the d-spacing is clearly amenable to the introduction of oxygen-containing functional groups between the layers, confirming the successful oxidation of graphite to graphene oxide [29]. An additional increase in $\mathrm{d}$-spacing $\left(\mathrm{d}_{001}=0.86 \mathrm{~nm}\right)$ was observed for $\mathrm{GO}^{-} \mathrm{TiO}_{2}$ hybrid material, with a broader and shifted basal reflection peak at $2 \theta=9.97^{\circ}$, corresponding to an intersheet separation of $\Delta=0.86-0.61=0.25 \mathrm{~nm}$, where $0.61 \mathrm{~nm}$ is the thickness of the GO monolayer [31]. This slight increase of the interlayer distance and the broadening of the associated reflection peak can be justified, taking into account two concomitant factors: (1) The use of nitric acid to promote the hydrolysis of titanium(IV) butoxide introduces more oxygen-containing functional groups onto the GO nanoplatelets resulting, in turn, in a higher separation of the graphene-oxide layers $[47,48]$ and (2) the reaction solution, inducing the exfoliation of the GO sheets, reduces the size of sheet stack (the thinner it is, the bigger is the reflection line broadening); therefore, a more relaxed stack results in a larger distance between individual GO sheets. With Scherrer's equation, we can roughly estimate the stack thickness and the average number of layers: For GO it is $27 \mathrm{~nm}$ with about 37 layers, which is reduced to about $9 \mathrm{~nm}$ with 10 layers for $\mathrm{GO}^{-\mathrm{TiO}_{2}}$.

In both cases, however, the presence of $\mathrm{TiO}_{2}$ nanoparticles grown onto the $\mathrm{GO}$ surface platelets prevented the restacking and the GO remained mostly exfoliated.

Finally, no diffraction peaks attributable to reflections from anatase or rutile crystal phases were observed [49], suggesting the complete amorphous nature of the $\mathrm{TiO}_{2}$ nanoparticles in the as-prepared nanohybrid. Indeed, the XRD pattern of the $\mathrm{GO}^{-\mathrm{TiO}_{2}}$ nanohybrid displays, together with the broader 
and shifted basal reflection peak with respect to the starting GO, a halo centered at $2 \theta=18^{\circ}$, evidence of the amorphous nature of the synthesized $\mathrm{TiO}_{2}$ (Figure 1).

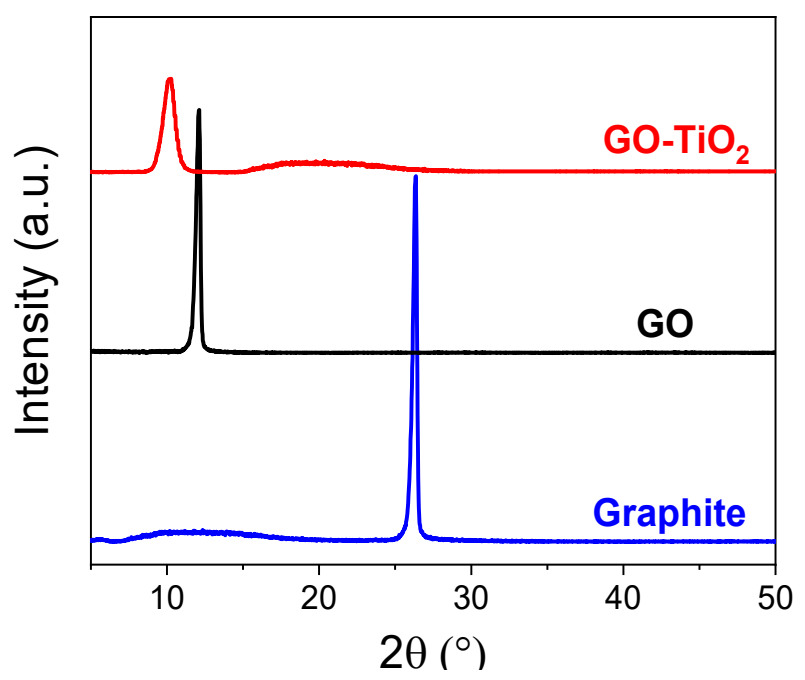

Figure 1. XRD patterns of graphene, $\mathrm{GO}$, and $\mathrm{GO}-\mathrm{TiO}_{2}$ nanostructured materials.

The crystalline structure of $\mathrm{GO}$ and $\mathrm{GO}-\mathrm{TiO}_{2}$ were further investigated by Raman analysis, the spectra of which are shown in Figure 2. The characteristic G- and D-bands of graphene oxide are observed at $\sim 1607$ and $\sim 1352 \mathrm{~cm}^{-1}$, respectively; the former related to the in-plane vibrations of $\mathrm{sp}^{2}$-bonded carbon atoms, the second to the presence of $\mathrm{sp}^{3}$ defect sites associated with vacancies and grain boundaries [50]. The peak intensity ratio $\left(I_{\mathrm{D}} / I_{\mathrm{G}}\right)$, which gives a measure of the structural defects in the graphite layer, was found to be 0.92 for the GO. Raman spectrum of the $\mathrm{GO}^{-\mathrm{TiO}_{2}}$ nanohybrid still displayed the two major characteristic peaks of graphene oxide and no additional crystalline bands were observed. This corroborates the amorphous nature of titanium dioxide rooted on the GO platelets. Additionally, the $I_{\mathrm{D}} / I_{\mathrm{G}}$ ratio increased to 0.97 , proving the partial reduction of $\mathrm{GO}$ following the hydrothermal process. Therefore, we can infer that the hybrid material consists of $\mathrm{TiO}_{2}$ particles decorating the graphene oxide nanosheets [51].

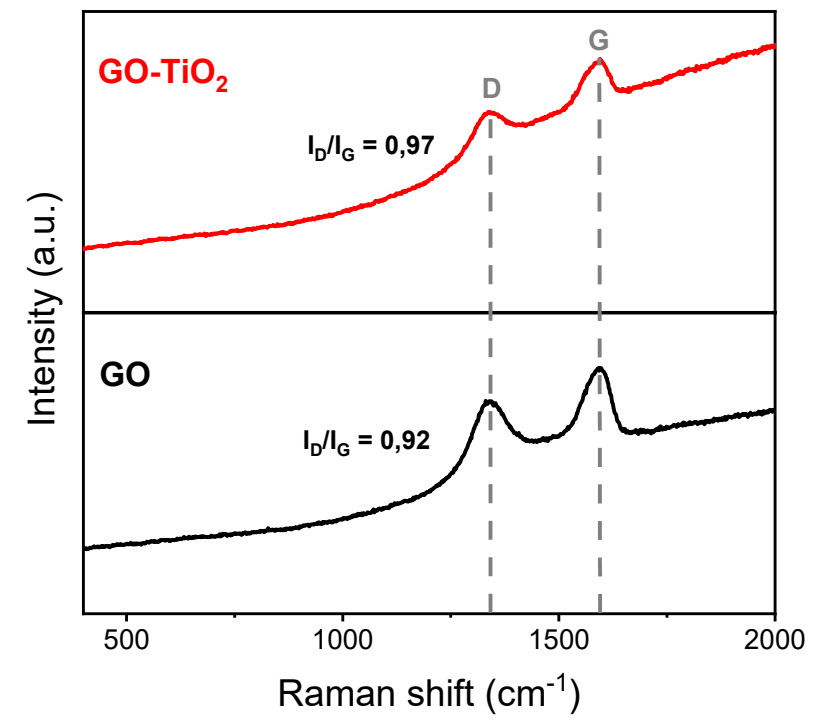

Figure 2. Raman spectra of GO and titania-functionalized GO.

FTIR spectra of GO and GO-TiO ${ }_{2}$ nanohybrid in the wavenumber range of $400-3750 \mathrm{~cm}^{-1}$ are reported in Figure 3. Graphene oxide exhibits the typical absorption bands of oxygen-containing 
functional groups: The apparent bands at 1070, 1240, 1384, and $1629 \mathrm{~cm}^{-1}$ are assigned to the characteristic vibrations of $\mathrm{C}-\mathrm{O}, \mathrm{C}-\mathrm{O}-\mathrm{C}$ (epoxy), $\mathrm{C}-\mathrm{OH}$ (alkoxy), and $\mathrm{C}=\mathrm{C}$ (aromatics) bonds, respectively. The stretching vibration of $\mathrm{C}=\mathrm{O}$ (carbonyl) and $\mathrm{O}-\mathrm{H}$ (hydroxyl) generates the other two absorption bands at 1745 and $3380 \mathrm{~cm}^{-1}$, respectively. These bands prove the effective synthesis of GO [25]. All signals strongly decrease in intensity in the $\mathrm{GO}_{-1 \mathrm{TiO}_{2}}$ material, suggesting the oxygen-containing functional groups are directly involved in the hydrolysis of the titania precursor [52]. Furthermore, two well-defined absorption bands also appear in the fingerprint region. This clearly originates from both the Ti-O-C stretching and the Ti-O-Ti vibration, generally occurring at $460 \mathrm{~cm}^{-1}$ and $530 \mathrm{~cm}^{-1}$, respectively [53]. Such features definitively confirm the $\mathrm{TiO}_{2}$ particles are chemically bonded to GO nanoplatelets, thus clearly proving the successful functionalization of graphene oxide embedded with $\mathrm{TiO}_{2}$ nanoparticles. Further undeniable evidence will be brought by SEM images and EDX analysis, reported below in the corresponding section.

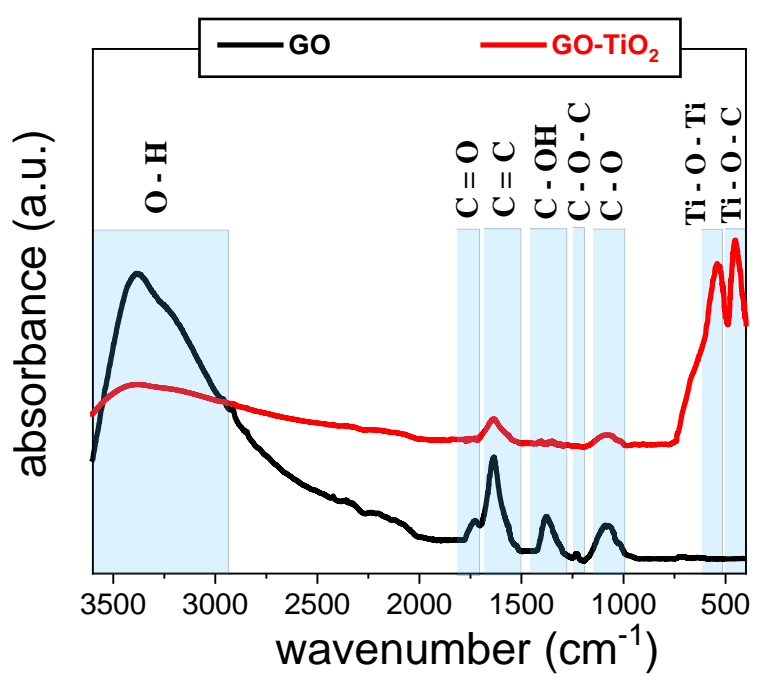

Figure 3. FTIR spectra of $\mathrm{GO}$ and $\mathrm{GO}-\mathrm{TiO}_{2}$ nanomaterials.

The TGA curves in Figure 4 show the weight loss of graphene oxide and its $\mathrm{TiO}_{2}$ derivative. The degradation of graphene oxide starts at almost $200{ }^{\circ} \mathrm{C}$ following the decomposition of oxygen-containing functional groups, whereas its honeycomb structure deteriorates above $400{ }^{\circ} \mathrm{C}$. For the $\mathrm{GO}-\mathrm{TiO}_{2}$, a third weight loss was also observed at $\mathrm{ca} .650^{\circ} \mathrm{C}$, likely due to the phase conversion from amorphous $\mathrm{TiO}_{2}$ to anatase. Noteworthy, the TGA results allow us to estimate a $\mathrm{TiO}_{2}$ content of $53.4 \%$ in the nanohybrid material.

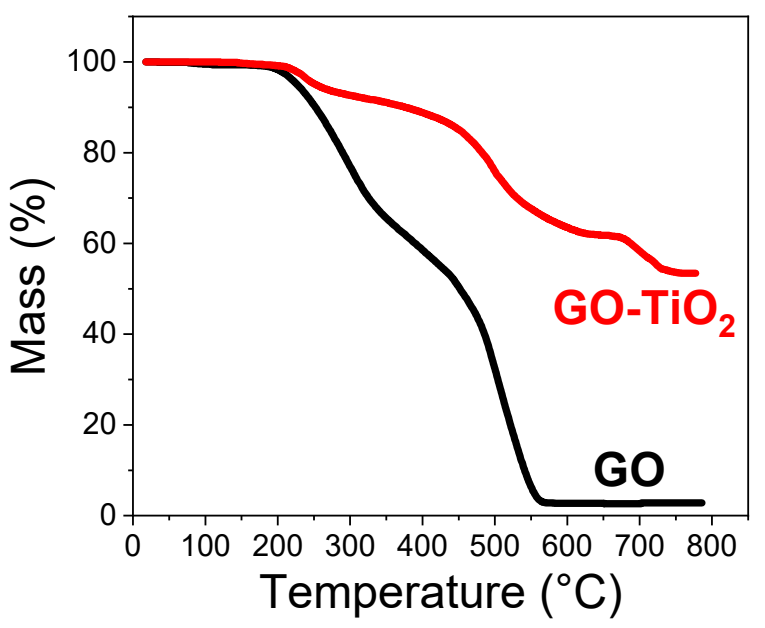

Figure 4. Thermogravimetric analysis (TGA) of GO and $\mathrm{GO}-\mathrm{TiO}_{2}$ materials. 


\subsection{The sPSU-Based Nanocomposite Membranes}

The synthetized $\mathrm{GO}_{-} \mathrm{TiO}_{2}$ nanohybrid material was used as nanoadditive for the preparation, via simple solution casting method, of sPSU-based nanocomposite membranes at various filler loadings $(2,3$, and $5 \mathrm{wt} . \%$, in respect to the polymer). As illustrated in Figure 5, filler-free sPSU membrane is completely transparent, whereas the color of the membranes changes from light gray to black (the color of $\mathrm{GO}-\mathrm{TiO}_{2}$ powder) as the filler loading increases and, in any case, they appear macroscopically homogeneous, smooth, and without any cracks or defects.

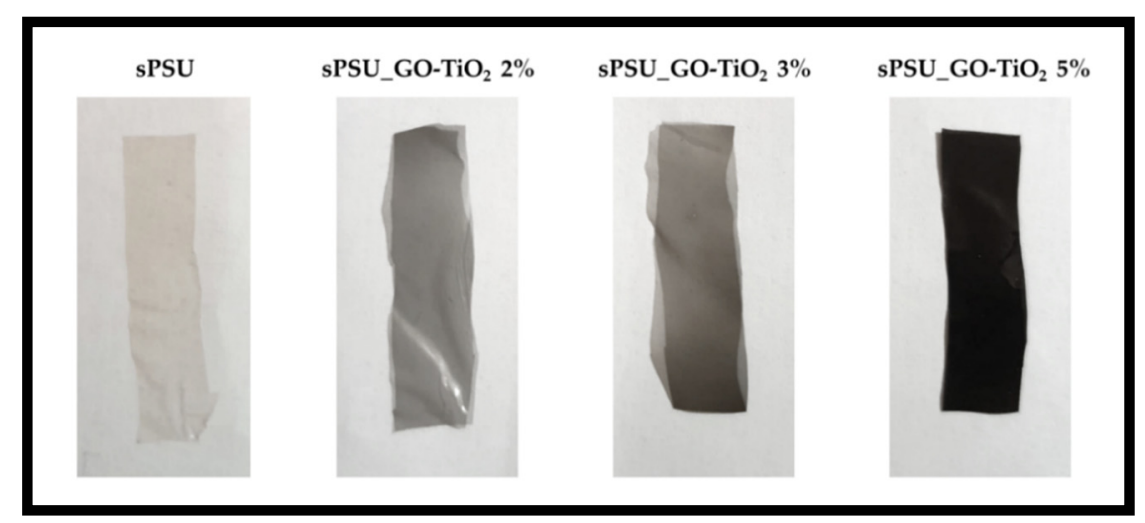

Figure 5. Photographs of sPSU and sPSU_GO-TiO 2 nanocomposite membranes.

Morphological analyses of the synthetized hybrid $\mathrm{GO}-\mathrm{TiO}_{2}$ material and membranes were performed by scanning electron microscopy (SEM) and are reported in Figure 6. The Figure 6a shows the nanoparticles of titania dispersed on the graphene platelets. Note that the GO nanoplatelets are no longer visible, due to their complete coverage by $\mathrm{TiO}_{2}$ nanoparticles. However, the composition of this material is confirmed by EDX analysis and is shown in the Figure $6 b$, which clearly reveals the presence of the $\mathrm{C}, \mathrm{O}$, and $\mathrm{Ti}$ elements only, accordingly with the $\mathrm{TiO}_{2}$ particles successfully grown onto the GO platelets' surface. Higher magnifications images are also shown in Figure $6 c, d$. The last one reports, in the inset, the intensity profile along the white line showing the typical dimension of the titania particles that range from $c a .50$ to $150 \mathrm{~nm}$. Noteworthy, the $\mathrm{TiO}_{2}$ particles decorating the platelets' surface should interfere with the restacking and, thus, favor the homogeneous dispersion of the $\mathrm{GO}-\mathrm{TiO}_{2}$ material in the polymer matrix. Note that some "blur" effect observed mainly on Figure $6 \mathrm{~b}, \mathrm{~d}$ at high magnification is only due to the small size of the $\mathrm{TiO}_{2}$ nanoparticles (less than $150 \mathrm{~nm})$.

Cross-section images of the sPSU_GO-TiO 2 and filler-free sPSU membranes at various magnifications are reported in Figure $6 \mathrm{e}-\mathrm{i}$, respectively. Both membranes show a dense, compact morphology, without pores or holes. However, while the filler-free sPSU section appears completely smooth and plain, the $\mathrm{GO}_{-} \mathrm{TiO}_{2}$-based nanoparticles are well visible throughout the whole membrane's thickness. Furthermore, at higher magnifications, Figure $6 \mathrm{f}, \mathrm{g}$, it can clearly be seen that their distribution is characterized by a certain directionality, roughly parallel to the surface. This is definitely related to the lamellar structure of GO, which induces such orientations' planes, and the $\mathrm{TiO}_{2}$ decoration emerges again clearly from these images as white spots. 


\section{$\mathrm{GO}-\mathrm{TiO}_{2}$ hybrid nanomaterial}
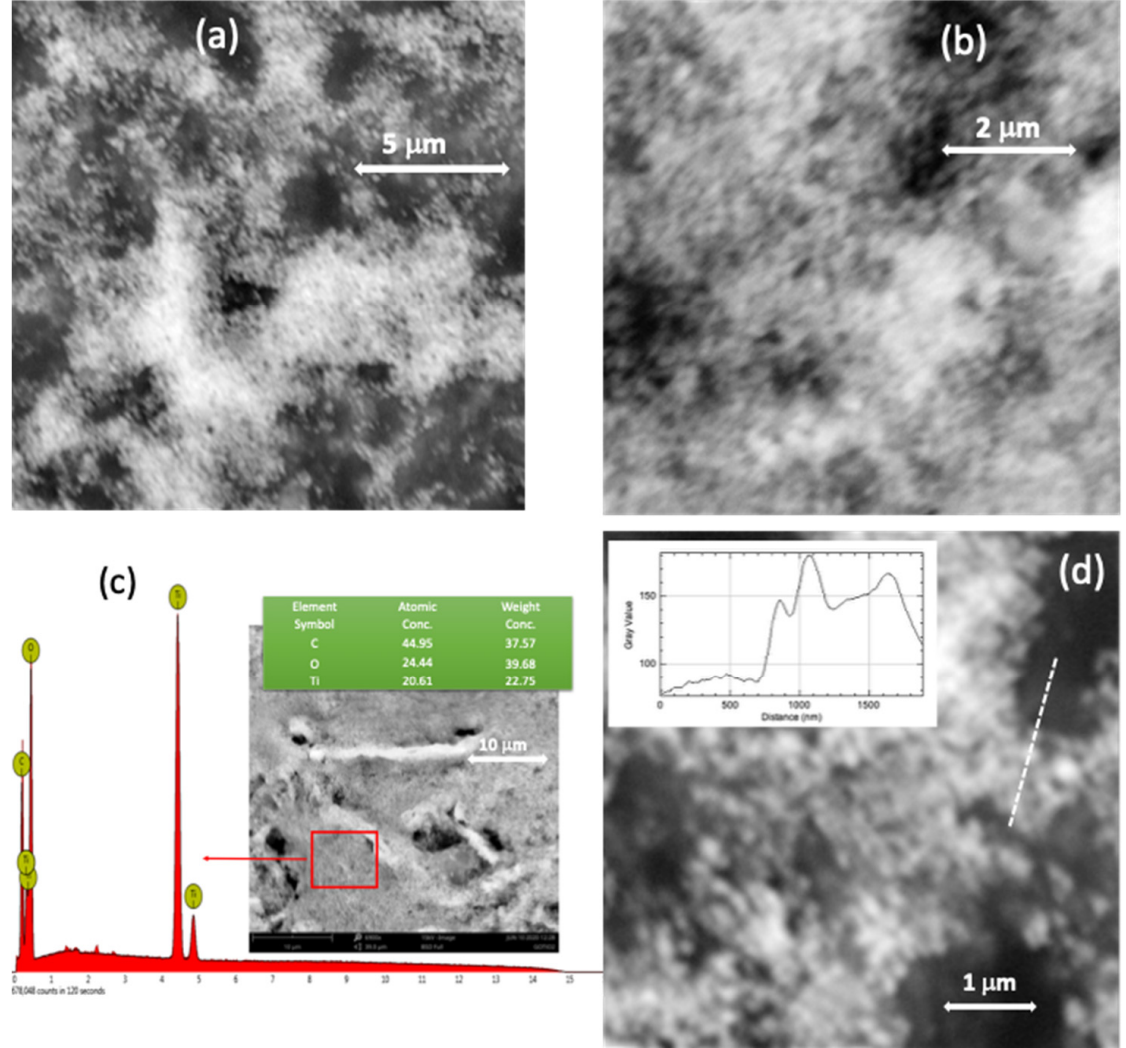

SPSU_GO-TiO ${ }_{2}$ membrane at 3 wt\% of filler loading
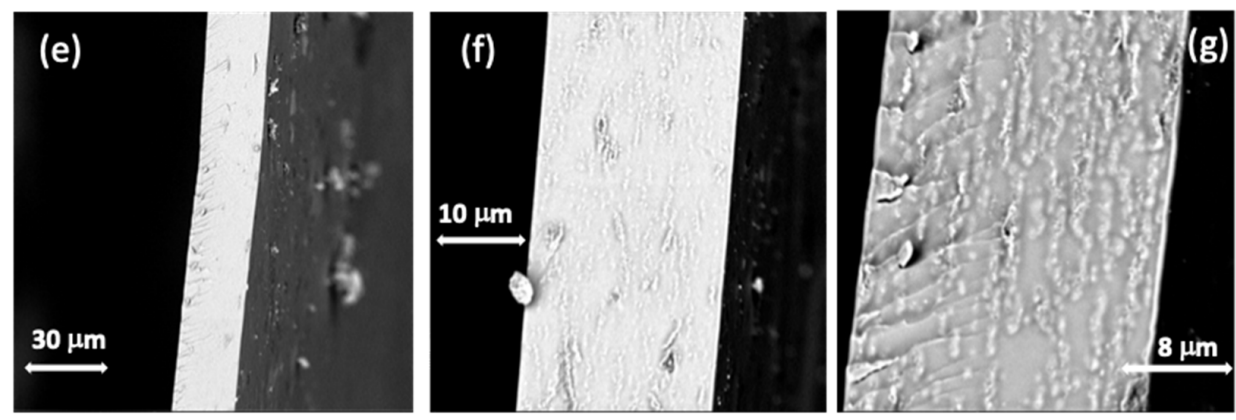

\section{sPSU filler-free membrane}
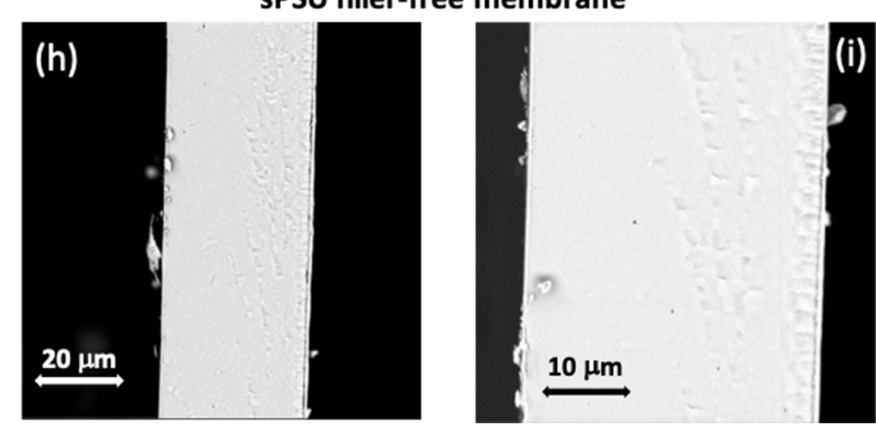

Figure 6. (a-d) SEM images at various magnifications of $\mathrm{GO}^{-\mathrm{TiO}_{2}}$ hybrid material and EDX spectrum, (e-g) cross-section images of sPSU_GO-TiO 2 composite membrane, $(\mathbf{h}, \mathbf{i})$ cross-section images of filler-free sPSU membrane.

As the core element in the fuel cell, the proton exchange membrane should guarantee excellent thermal and mechanical resistance during the long-time operation. The thermal properties of the 
membranes were investigated by TGA (Figure 7): Two main degradation weight-loss stages are clearly detectable, the first one between $240{ }^{\circ} \mathrm{C}$ and $350^{\circ} \mathrm{C}$, which can be attributed to the pyrolysis of the sulfonic acid groups, and the second stage at about $400{ }^{\circ} \mathrm{C}$, assigned to the degradation of the polymer backbone. In comparison to the filler-free membrane, in the nanocomposites both thermal degradation steps are significantly shifted upward, indicating higher thermal stability than the pristine sPSU. This result suggests a strong interaction between the $\mathrm{GO}-\mathrm{TiO}_{2}$ hybrid material and the polymer, while the high alteration of the TGA signal upon addition of the filler typically implies that it is homogeneously dispersed in the sPSU matrix [54,55].

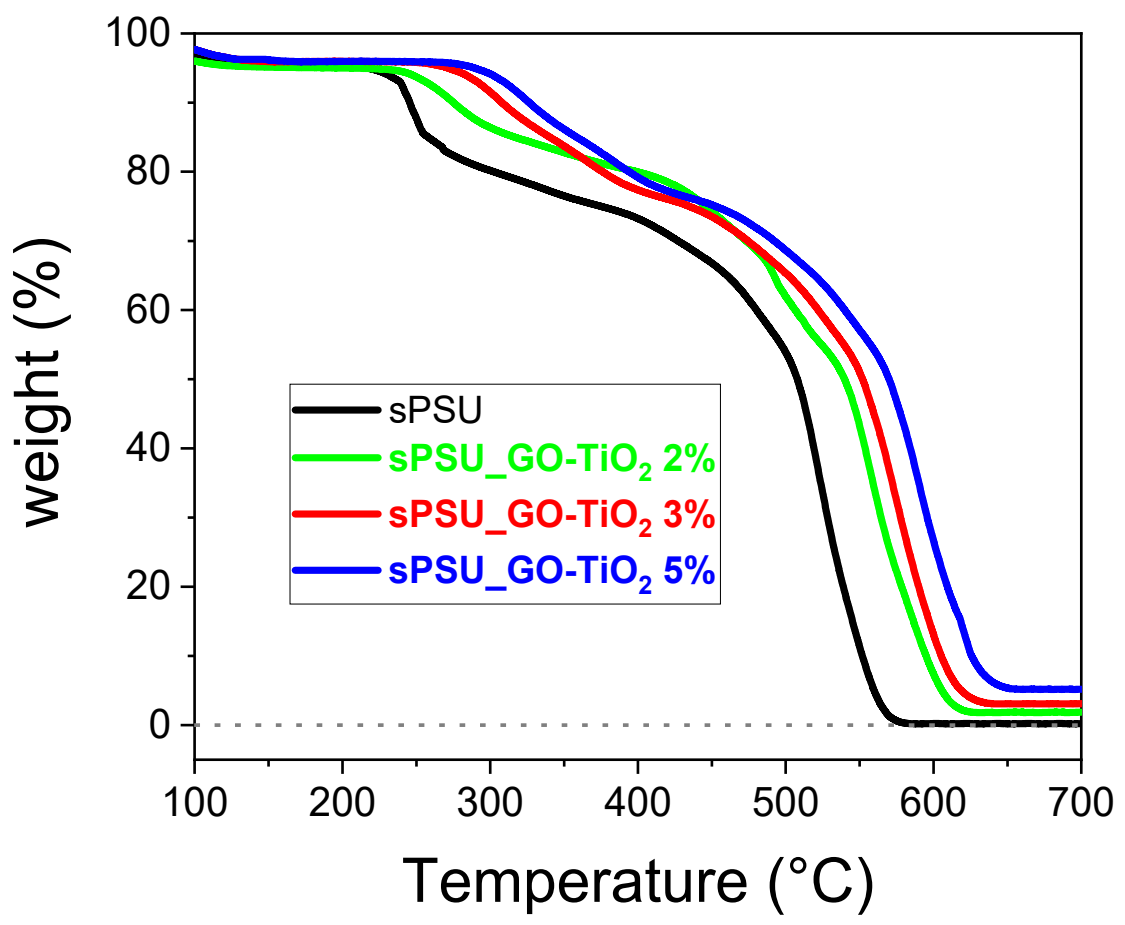

Figure 7. TGA curves of sPSU and sPSU_GO-TiO ${ }_{2}$ composite membranes.

The trends observed above are further supported by DMA data. Figure 8a shows the temperature evolution of the $\tan \delta$ for all the investigated membranes, providing a clear picture of the relationship between the filler content and the thermal stability of the resulting PEM. For comparison, the thermo-mechanical features of the commercial Nafion 212 membrane have also been plotted. The glass transition temperature of the hybrid composite membranes progressively shift toward higher temperature with the increase of the filler loading: From the initial value of about $200^{\circ} \mathrm{C}$ of the filler-free sPSU membrane, up to $240{ }^{\circ} \mathrm{C}$ for the nanocomposite with $5 \mathrm{wt} . \%$ of filler. Compared to Nafion 212, which displays the typical $\mathrm{T}_{\mathrm{g}}$ at $\sim 125{ }^{\circ} \mathrm{C}$, the thermo-mechanical stability window for these hybrid membranes extends significantly. Moreover, the presence of the $\mathrm{GO}-\mathrm{TiO}_{2}$ nanohybrid produces a significant increasing of the storage modulus $\left(\mathrm{E}^{\prime}\right)$ of the composite membranes (Figure $8 \mathrm{~b}$ ). The highest $\mathrm{E}^{\prime}$ value is achieved by the sPSU_GO-TiO $2(5 \%)$ composite film ( $\left.1330 \mathrm{MPa}\right)$, which is about three-fold higher than the sPSU pristine membrane ( 400 MPa) and even almost two order of magnitude higher than the Nafion benchmark (19 MPa). Such remarkable result is likely amenable to both the peculiar architecture of $\mathrm{GO}_{-} \mathrm{TiO}_{2}$ (which combines the mechanical features of $2 \mathrm{D}$, layered materials together with the nanodispersion of the titanium dioxide) and the high chemical affinity between polymer and hybrid material which produces a highly stable network [56,57]. Definitely, the sPSU_GO-TiO ${ }_{2}$ nanocomposites ensure a significant step forward with respect to the state-of-the-art Nafion, since they can effectively withstand higher working temperatures and more severe mechanical stress. 


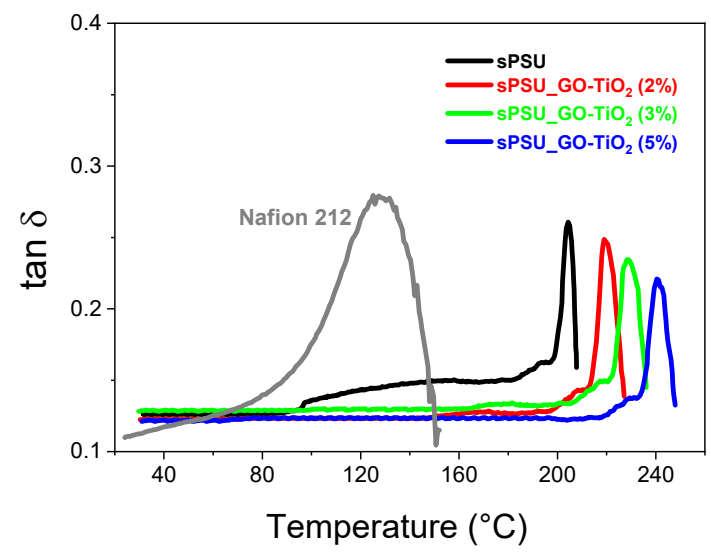

(a)

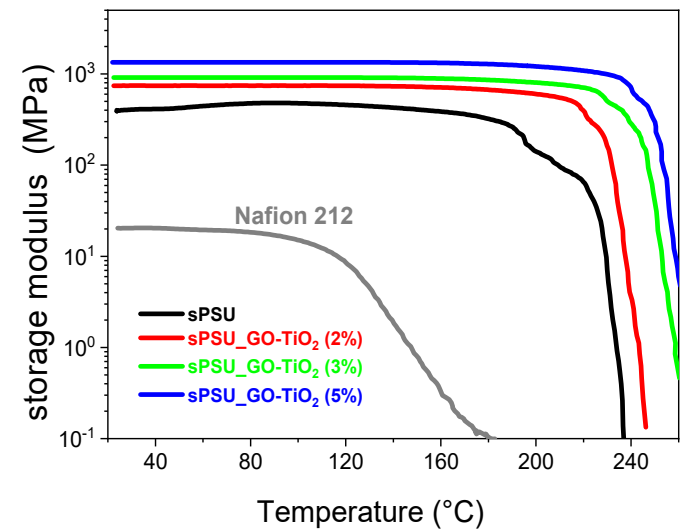

(b)

Figure 8. Tan $\delta(\mathbf{a})$ and storage modulus $E^{\prime}(\mathbf{b})$ versus temperature of pristine sPSU and nanocomposite membranes containing $\mathrm{GO}-\mathrm{TiO}_{2}$. Commercial Nafion 212 membrane is also reported for comparison.

Table 1 reports the ion exchange capacity (IEC) and the water uptake (WU) as a function of the filler content. While the IEC relates to the number of $\mathrm{H}^{+}$-transporting functional groups in the membrane, the water uptake is also a crucial factor since it directly affects the proton conductivity and the dimensional stability of the PEM [58]. The presence of the filler produces a sensible increasing of both IEC and WU of the membranes, due to the hygroscope and proton conductor nature of the GO- $\mathrm{TiO}_{2}$ nanoplatelets. The maximum values are reached with $3 \mathrm{wt}$. $\%$ of filler, which then goes down with an ulterior load, probably due to some degree of particle agglomeration.

Table 1. Main chemical-physical characteristic of sPSU-based membranes.

\begin{tabular}{lcc}
\hline \multicolumn{1}{c}{ Membrane } & $\begin{array}{c}\text { IEC } \\
{\left[\mathbf{m e q ~}^{\mathbf{- 1}} \text { ] }\right.}\end{array}$ & $\begin{array}{c}\text { Water Uptake } \\
\text { [\%] }\end{array}$ \\
\hline sPSU & $1.36 \pm 0.01$ & $27.2 \pm 0.1$ \\
sPSU_GO-TiO 2 2 $\%$ & $1.40 \pm 0.02$ & $31.6 \pm 0.2$ \\
sPSU_GO-TiO 2 3\% & $1.43 \pm 0.02$ & $33.4 \pm 0.3$ \\
sPSU_GO-TiO 2 5\% & $1.42 \pm 0.01$ & $31.8 \pm 0.2$ \\
\hline
\end{tabular}

The ${ }^{1} \mathrm{H}$-PFG NMR spectroscopy is a powerful technique to deeply investigate the protons' transport properties in electrolyte membranes, through the direct measurements of the self-diffusion coefficients (D) [59-63]. Figure 9 shows the temperature behavior, in the range $20-130{ }^{\circ} \mathrm{C}$, of the water diffusivity in the hydrophilic pores of the swollen membranes. $\mathrm{D}$ increases with heating due to the thermal energy absorbed by the water molecules, but as it approaches $80-100{ }^{\circ} \mathrm{C}$, the diffusion coefficients start to decrease in value for the nonnegligible evaporation process of the bulk-like water from the membrane (note that during NMR measurements the membrane is not provided with additional humidification). Above this temperature, the contribution to the diffusion coefficient comes from the mobility of hydration water to acid sites of polymer (sulfonic groups) and nanofiller (carboxyl and hydroxyl groups of GO and acid surface of titania).

However, different behavior was observed among the investigated samples:

(1) Water diffusion is higher in the nanocomposite membranes than in the filler-free sPSU;

(2) The highest values are displayed by the sample at $3 \mathrm{wt} . \%$ of loading, which is also the membrane with the highest EIC and WU, confirming that agglomeration of the filler particles and occlusion of the hydrophilic cluster of sPSU occurs at higher loading;

(3) The downfall of D at high temperatures is critical (and similar to the pristine membrane) for the composite sPSU_GO- $\mathrm{TiO}_{2} 5 \%$, while it is progressively less accentuated in the others, even becoming a plateau for the sPSU_GO-TiO 2 3\% membrane; 
(4) At $130{ }^{\circ} \mathrm{C}$ the $\mathrm{D}$ value in $\mathrm{sPSU} \_\mathrm{GO}-\mathrm{TiO}_{2} 3 \%$ is almost two order of magnitude higher than in the pristine $\mathrm{sPSU}$, i.e., $1.1 \times 10^{-5}$ and $1.3 \times 10^{-7} \mathrm{~cm}^{2} \mathrm{~s}^{-1}$, respectively.

These experimental data highlight, on the one hand, the effectiveness of a hydrophilic hybrid material such as the one proposed, within a polymer matrix, in order to promote both water retention at high temperatures and proton transport properties and, on the other hand, the fact that, only by creating the right polymer-filler network, interconnected routes for the transport of protons in difficult operating conditions can be built.

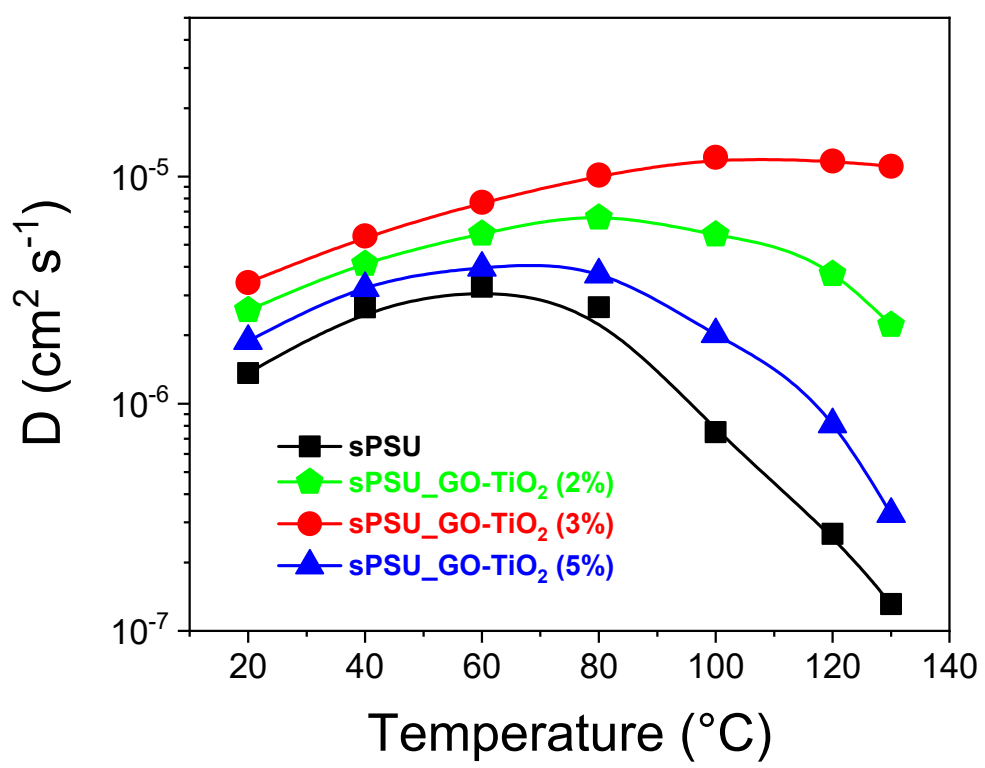

Figure 9. Water self-diffusion coefficient in sPSU and nanocomposite membranes in the temperature range $20-130{ }^{\circ} \mathrm{C}$.

Proton conductivity $(\sigma)$ of the membranes at $80{ }^{\circ} \mathrm{C}$ and under different $\mathrm{RH}$ conditions (from 20 to $100 \% \mathrm{RH}$ ) are shown in Figure 10a in comparison with commercial Nafion 212 membrane as a benchmark. Some representative values are also reported in Table 2. Obtained data are in agreement with the diffusion coefficients seen above.

For pristine sPSU, conductivity at this temperature ranged between about $50 \mathrm{mS} \mathrm{cm}^{-1} @ 100 \% \mathrm{RH}$ and $1 \mathrm{mS} \mathrm{cm}^{-1} @ 20 \%$ RH. The best performance was obtained from sPSU_GO-TiO $23 \%$ which, in fully humidified conditions, reached about $100 \mathrm{mS} \mathrm{cm}^{-1}$, i.e., twice as much as the sample without filler, but slightly lower than the Nafion benchmark. However, the performance of this hybrid membrane became interesting when the relative humidity was extremely low, which is a prerequisite for the development of PEMFCs able to operate under harsh conditions. In fact, if at RH 50\% the proton conductivity is similar to that of Nafion, at RH $20 \%$, it was two-fold higher than the benchmark. This outcome clearly indicates that titanium oxide nanoparticles are able to retain a certain amount of hydration water molecules on their surface and that the hybrid material creates an architecture with the polymer chains, which promote the Grotthuss-type mechanism as a more efficient route for the proton transport [64].

Figure 10b shows the relative variation of $\sigma$ during long-time operation (over $140 \mathrm{~h}$ ) at $80^{\circ} \mathrm{C}$ and $100 \% \mathrm{RH}$, for the two representative samples, sPSU and sPSU_GO-TiO ${ }_{2} 3 \%$. It was reported that small changes in proton conductivity are due to sufficient hydrolysis stability [65]. In the filler-free sPSU, conductivity reached a plateau after $80 \mathrm{~h}$, with an overall loss of almost $14 \%$, while it was completely negligible in the nanocomposite (less than 3\%). The reason for this behavior is related to the partial decomposition that sulfonic acid groups of sulfonated polyaromatic polymers undergoes in aqueous environment. However, the strong electrostatic interaction with the $\mathrm{GO}^{-\mathrm{TiO}_{2}}$ nanohybrid particles 
seems to prevent (or strongly delay) the degradation of structural $-\mathrm{SO}_{3} \mathrm{H}$ in sPSU, thus remarkably enhancing the hydrolytic stability of the resulting membrane.

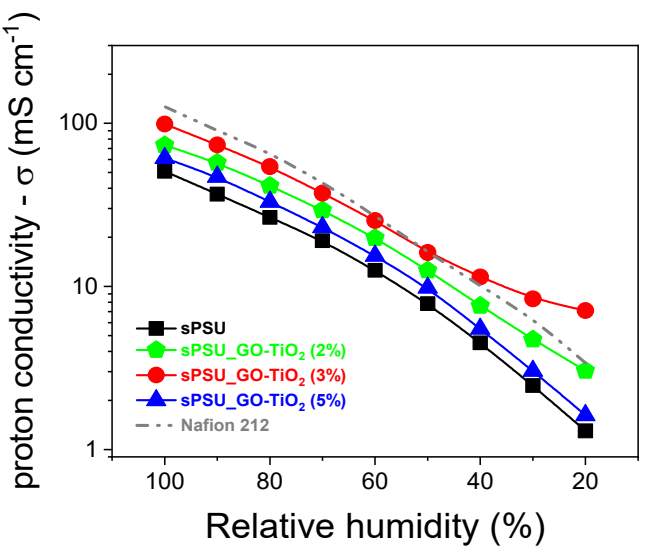

(a)

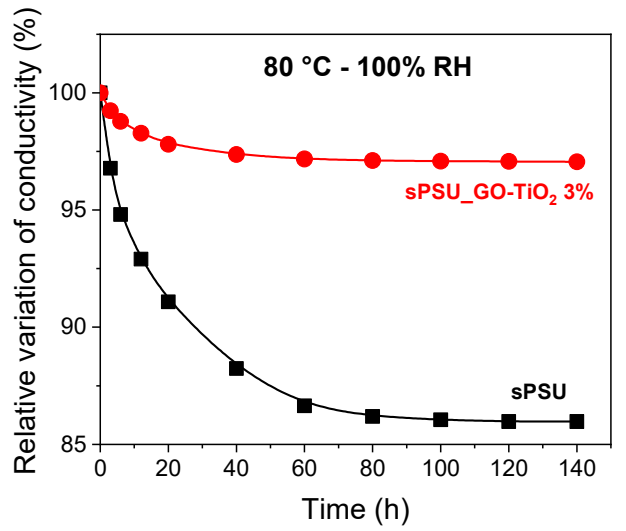

(b)

Figure 10. (a) Proton conductivity of sPSU-based membranes and commercial Nafion 212 membrane at $80^{\circ} \mathrm{C}$ as a function of the relative humidity $(\mathrm{RH} \%),(\mathbf{b})$ relative variation of $\sigma$ in the time (for $140 \mathrm{~h}$ ), at $80{ }^{\circ} \mathrm{C}$ and $100 \% \mathrm{RH}$.

Table 2. Proton conductivity of sPSU and nanocomposite membranes as a function of $\mathrm{RH}$ at $80^{\circ} \mathrm{C}$.

\begin{tabular}{|c|c|c|c|c|}
\hline \multirow{2}{*}{ Membrane } & \multicolumn{4}{|c|}{ Proton Conductivity $\left(\mathrm{mS} \mathrm{cm}^{-1}\right)$} \\
\hline & $20 \% \mathrm{RH}$ & $50 \%$ RH & $80 \%$ RH & $100 \% \mathrm{RH}$ \\
\hline sPSU & 1.30 & 7.84 & 26.46 & 50.70 \\
\hline sPSU_GO-TiO $2 \%$ & 3.04 & 12.55 & 41.39 & 73.46 \\
\hline sPSU_GO-TiO $23 \%$ & 7.11 & 16.14 & 54.20 & 98.91 \\
\hline sPSU_GO-TiO 2 5\% & 1.62 & 9.81 & 33.01 & 61.15 \\
\hline Nafion 212 & 3.39 & 16.12 & 65.90 & 126.03 \\
\hline
\end{tabular}

\section{Conclusions}

$\mathrm{TiO}_{2}$ nanoparticles were successfully grown onto graphene oxide platelets by a simple one-pot hydrothermal procedure, and the $\mathrm{GO}_{-} \mathrm{TiO}_{2}$ nanohybrid material was homogeneously dispersed within a sulfonated polysulfone (sPSU) matrix for the preparation of new nanocomposite electrolyte PEMs, sPSU_GO-TiO 2 , at various filler loadings.

The architecture of the GO-TiO 2 hybrid material was analyzed by SEM/EDX and well defined by Raman, XRD, and FTIR spectroscopies, obtaining strong evidence that the $\mathrm{TiO}_{2}$ nanoparticles are covalently grafted onto the GO platelets. The titania content on graphene platelets was estimated by TGA at about $53 \%$ in weight, and SEM images showed that the GO nanoplatelets were completely covered by $\mathrm{TiO}_{2}$ nanoparticles, the size of which ranged from 50 to $150 \mathrm{~nm}$ diameter.

The addition of such $\mathrm{GO}-\mathrm{TiO}_{2}$ hybrid material to the polymer produced a remarkable improvement of the mechanical properties of the nanocomposite membranes, with an increasing of the storage modulus three-fold higher than the filler-free sPSU membrane, as well as a forward shift of the polymer's glass transition. This is due to the uniform distribution of the filler in the polymer matrix, as evidenced by SEM morphological analysis.

EIS and NMR demonstrated the high water-retention capacity at high temperatures of the composite membrane at $3 \mathrm{wt}$.\% filler loading, as well as a remarkable proton mobility, especially in low relative humidity conditions, suggesting that an architecture between polymer and filler was created with interconnected routes for an efficient proton transport, and marking a step ahead of the state of the art in PEMs. 
In addition, the strong interactions between polymer chains and $\mathrm{GO}_{-} \mathrm{TiO}_{2}$ nanoparticles increased the hydrolytic stability of the composite membrane, since structural degradation phenomena of the sulfonic groups of sPSU were drastically reduced.

Author Contributions: Conceptualization, I.N. and D.G.; methodology, C.S., L.C., and D.G.; validation, I.N.; formal analysis, C.S. and L.C.; investigation, C.S., N.G., and E.L.; resources, I.N. and D.G.; data curation, C.S. and E.L.; writing-original draft preparation, C.S.; writing-review and editing, I.N.; supervision, I.N.; funding acquisition, I.N.; All authors have read and agreed to the published version of the manuscript.

Funding: This research was supported by ComESto Project (“Gestione aggregata di Sistemi di accumulo dell'energia in Power Cloud"), PNR 2015-2020 of the Italian Ministry of Education, Universities and Research (MIUR).

Acknowledgments: Paolino Caputo (University of Calabria) is gratefully acknowledged for the technical assistance with TGA analysis.

Conflicts of Interest: The authors declare that there is no conflict of interests.

\section{References}

1. Steele, B.C.H.; Heinzel, A. Materials for Fuel-Cell Technologies. Nature 2001, 414, 345-352. [CrossRef] [PubMed]

2. Zhang, H.; Shen, P.K. Recent development of polymer electrolyte membranes for fuel cells. Chem. Rev. 2012, 112, 2780-2832. [CrossRef] [PubMed]

3. Chandan, A.; Hattenberger, M.; El-kharouf, A.; Du, S.; Dhir, A.; Self, V.; Pollet, B.G.; Ingram, A.; Bujalski, W. High temperature (HT) polymer electrolyte membrane fuel cells (PEMFC) e A review. J. Power Sources 2013, 231, 264-278. [CrossRef]

4. Inzelt, G.; Pineri, M.; Schultze, J.W.; Vorotyntsev, M.A. Electron and proton conducting polymers: Recent developments and prospects. Electrochim. Acta 2000, 45, 2403-2421. [CrossRef]

5. Esmaeili, N.; Gray, E.M.A.; Webb, C.J. Non-Fluorinated Polymer Composite Proton Exchange Membranes for Fuel Cell Applications-A Review. ChemPhysChem 2019, 20, 2016-2053. [CrossRef] [PubMed]

6. Kreuer, K.D. On the development of proton conducting polymer membranes for hydrogen and methanol fuel cells. J. Memb. Sci. 2001, 185, 29-39. [CrossRef]

7. Simari, C.; Enotiadis, A.; Nicotera, I. Transport Properties and Mechanical Features of Sulfonated Polyether Ether Ketone/Organosilica Layered Materials Nanocomposite Membranes for Fuel Cell Applications. Membranes 2020, 10, 87. [CrossRef]

8. Kim, J.D.; Ohira, A.; Nakao, H. Chemically crosslinked sulfonated polyphenylsulfone (CSPPSU) membranes for PEM fuel cells. Membranes 2020, 10, 31. [CrossRef]

9. Savinell, R.F.; Litt, M.H. Proton Conducting Polymers Used as Membranes. U.S. Patent 5,525,436, 6 November 1996.

10. Nicotera, I.; Kosma, V.; Simari, C.; Angioni, S.; Mustarelli, P.; Quartarone, E. Ion dynamics and mechanical properties of sulfonated polybenzimidazole membranes for high-temperature proton exchange membrane fuel cells. J. Phys. Chem. C 2015, 119, 9745-9753. [CrossRef]

11. Donnadio, A.; Casciola, M.; Di Vona, M.L.; Tamilvanan, M. Conductivity and hydration of sulfonated polyethersulfone in the range $70-120^{\circ} \mathrm{C}$ : Effect of temperature and relative humidity cycling. J. Power Sources 2012, 205, 145-150. [CrossRef]

12. Simari, C.; Vecchio, C.L.; Enotiadis, A.; Davoli, M.; Baglio, V.; Nicotera, I. Toward optimization of a robust low-cost sulfonated-polyethersulfone containing layered double hydroxide for PEM fuel cells. J. Appl. Polym. Sci. 2019, 136, 47884. [CrossRef]

13. De Bonis, C.; Simari, C.; Kosma, V.; Mecheri, B.; D’Epifanio, A.; Allodi, V.; Mariotto, G.; Brutti, S.; Suarez, S.; Pilar, K.; et al. Enhancement of proton mobility and mitigation of methanol crossover in sPEEK fuel cells by an organically modified titania nanofiller. J. Solid State Electrochem. 2016, 20, 1585-1598. [CrossRef]

14. Lufrano, F.; Gatto, I.; Staiti, P.; Antonucci, V.; Passalacqua, E. Sulfonated polysulfone ionomer membranes for fuel cells. Solid State Ion. 2001, 145, 47-51. [CrossRef]

15. Lufrano, E.; Simari, C.; Lo Vecchio, C.; Aricò, A.S.; Baglio, V.; Nicotera, I. Barrier properties of sulfonated polysulfone/layered double hydroxides nanocomposite membrane for direct methanol fuel cell operating at high methanol concentrations. Int. J. Hydrogen Energy 2020, 45, 20647-20658. [CrossRef] 
16. Yamada, O.; Yin, Y.; Tanaka, K.; Kita, H.; Okamoto, K.I. Polymer electrolyte fuel cells based on main-chain-type sulfonated polyimides. Electrochim. Acta 2005, 50, 2655-2659. [CrossRef]

17. Laberty-Robert, C.; Vallé, K.; Pereira, F.; Sanchez, C. Design and properties of functional hybrid organic-inorganic membranes for fuel cells. Chem. Soc. Rev. 2011, 40, 961-1005. [CrossRef]

18. Simari, C.; Lufrano, E.; Coppola, L.; Nicotera, I. Composite gel polymer electrolytes based on organo-modified nanoclays: Investigation on lithium-ion transport and mechanical properties. Membranes 2018, 8, 69. [CrossRef]

19. Silva, V.S.; Schirmer, J.; Reissner, R.; Ruffmann, B.; Silva, H.; Mendes, A.; Madeira, L.M.; Nunes, S.P. Proton electrolyte membrane properties and direct methanol fuel cell performance-II. Fuel cell performance and membrane properties effects. J. Power Sources 2005, 140, 41-49. [CrossRef]

20. Şengül, E.; Erdener, H.; Akay, R.G.; Yücel, H.; Baç, N.; Eroğlu, I.I. Effects of sulfonated polyether-etherketone (SPEEK) and composite membranes on the proton exchange membrane fuel cell (PEMFC) performance. Int. J. Hydrogen Energy 2009, 34, 4645-4652.

21. Chen, S.Y.; Han, C.C.; Tsai, C.H.; Huang, J.; Chen-Yang, Y.W. Effect of morphological properties of ionic liquid-templated mesoporous anatase $\mathrm{TiO}_{2}$ on performance of PEMFC with $\mathrm{Nafion} / \mathrm{TiO}_{2}$ composite membrane at elevated temperature and low relative humidity. J. Power Sources 2007, 171, 363-372. [CrossRef]

22. Hill, M.L.; Kim, Y.S.; Einsla, B.R.; McGrath, J.E. Zirconium hydrogen phosphate/disulfonated poly(arylene ether sulfone) copolymer composite membranes for proton exchange membrane fuel cells. J. Memb. Sci. 2006, 283, 102-108. [CrossRef]

23. Simari, C.; Enotiadis, A.; Lo Vecchio, C.; Baglio, V.; Coppola, L.; Nicotera, I. Advances in hybrid composite membranes engineering for high-performance direct methanol fuel cells by alignment of 2D nanostructures and a dual-layer approach. J. Memb. Sci. 2020, 599, 117858. [CrossRef]

24. Dikin, D.A.; Stankovich, S.; Zimney, E.J.; Piner, R.D.; Dommett, G.H.B.; Evmenenko, G.; Nguyen, S.T.; Ruoff, R.S. Preparation and characterization of graphene oxide paper. Nature 2007, 448, 457-460. [CrossRef] [PubMed]

25. Simari, C.; Stallworth, P.; Peng, J.; Coppola, L.; Greenbaum, S.; Nicotera, I. Graphene oxide and sulfonated-derivative: Proton transport properties and electrochemical behavior of Nafion-based nanocomposites. Electrochim. Acta 2019, 297, 240-249. [CrossRef]

26. Yang, H.N.; Lee, W.H.; Choi, B.S.; Kim, W.J. Preparation of Nafion/Pt-containing $\mathrm{TiO}_{2} /$ graphene oxide composite membranes for self-humidifying proton exchange membrane fuel cell. J. Memb. Sci. 2016, 504, 20-28. [CrossRef]

27. Yadav, R.; Subhash, A.; Chemmenchery, N.; Kandasubramanian, B. Graphene and Graphene Oxide for Fuel Cell Technology. Ind. Eng. Chem. Res. 2018, 57, 9333-9350. [CrossRef]

28. Koduru, H.K.; Scarpelli, F.; Marinov, Y.G.; Hadjichristov, G.B.; Rafailov, P.M.; Miloushev, I.K.; Petrov, A.G.; Godbert, N.; Bruno, L.; Scaramuzza, N. Characterization of PEO/PVP/GO nanocomposite solid polymer electrolyte membranes: Microstructural, thermo-mechanical, and conductivity properties. Ionics (Kiel) 2018, 24, 3459-3473. [CrossRef]

29. Dreyer, D.R.; Park, S.; Bielawski, C.W.; Ruoff, R.S. The chemistry of graphene oxide. Chem. Soc. Rev. 2010, 39, 228-240. [CrossRef]

30. Zarrin, H.; Higgins, D.; Jun, Y.; Chen, Z.; Fowler, M. Functionalized graphene oxide nanocomposite membrane for low humidity and high temperature proton exchange membrane fuel cells. J. Phys. Chem. C 2011, 115, 20774-20781. [CrossRef]

31. Enotiadis, A.; Angjeli, K.; Baldino, N.; Nicotera, I.; Gournis, D. Graphene-based nafion nanocomposite membranes: Enhanced proton transport and water retention by novel organo-functionalized graphene oxide nanosheets. Small 2012, 8, 3338-3349. [CrossRef]

32. Xu, C.; Cao, Y.; Kumar, R.; Wu, X.; Wang, X.; Scott, K. A polybenzimidazole/sulfonated graphite oxide composite membrane for high temperature polymer electrolyte membrane fuel cells. J. Mater. Chem. 2011, 21, 11359-11364. [CrossRef]

33. Bai, H.; Li, Y.; Zhang, H.; Chen, H.; Wu, W.; Wang, J.; Liu, J. Anhydrous proton exchange membranes comprising of chitosan and phosphorylated graphene oxide for elevated temperature fuel cells. J. Memb. Sci. 2015, 495, 48-60. [CrossRef] 
34. He, Y.; Wang, J.; Zhang, H.; Zhang, T.; Zhang, B.; Cao, S.; Liu, J. Polydopamine-modified graphene oxide nanocomposite membrane for proton exchange membrane fuel cell under anhydrous conditions. J. Mater. Chem. A 2014, 2, 9548-9558. [CrossRef]

35. Lanin, S.N.; Vlasenko, E.V.; Kovaleva, N.V.; Zung, F.T. The adsorption properties of titanium dioxide. Russ. J. Phys. Chem. A 2008, 82, 2152-2155. [CrossRef]

36. Nicotera, I.; Khalfan, A.; Goenaga, G.; Zhang, T.; Bocarsly, A.; Greenbaum, S. NMR investigation of water and methanol mobility in nanocomposite fuel cell membranes. Ionics 2008, 14, 243-253. [CrossRef]

37. Kusiak-Nejman, E.; Moszyński, D.; Kapica-Kozar, J.; Wanag, A.; Morawski, A.W. Assessment of the suitability of the one-step hydrothermal method for preparation of non-covalently/covalently-bonded $\mathrm{TiO}_{2} /$ graphene-based hybrids. Nanomaterials 2018, 8, 647. [CrossRef]

38. Liang, D.; Cui, C.; Hub, H.; Wang, Y.; Xu, S.; Ying, B.; Li, P.; Lu, B.; Shen, H. One-step hydrothermal synthesis of anatase $\mathrm{TiO} 2 /$ reduced graphene oxide nanocomposites with enhanced photocatalytic activity. J. Alloys Compd. 2014, 582, 236-240. [CrossRef]

39. Williams, G.; Seger, B.; Kamat, P. V UV-Assisted Photocatalytic Reduction of Graphene Oxide. ACS Nano 2008, 2, 1487-1491. [CrossRef]

40. Lufrano, F.; Baglio, V.; Staiti, P.; Arico', A.S.; Antonucci, V. Development and characterization of sulfonated polysulfone membranes for direct methanol fuel cells. Desalination 2006, 199, 283-285. [CrossRef]

41. Nicotera, I.; Simari, C.; Agostini, M.; Enotiadis, A.; Brutti, S. A Novel Li + - Na fi on-Sulfonated Graphene Oxide Membrane as Single Lithium-Ion Conducting Polymer Electrolyte for Lithium Batteries. J. Phys. Chem. C 2019, 123, 27406-27416. [CrossRef]

42. Nicotera, I.; Simari, C.; Coppola, L.; Zygouri, P.; Gournis, D.; Brutti, S.; Minuto, F.D.; Aricò, A.S.; Sebastian, D.; Baglio, V. Sulfonated graphene oxide platelets in nafion nanocomposite membrane: Advantages for application in direct methanol fuel cells. J. Phys. Chem. C 2014, 118, 24357-24368. [CrossRef]

43. Nicotera, I.; Kosma, V.; Simari, C.; D’Urso, C.; Aricò, A.S.; Baglio, V. Methanol and proton transport in layered double hydroxide and smectite clay-based composites: Influence on the electrochemical behavior of direct methanol fuel cells at intermediate temperatures. J. Solid State Electrochem. 2015, 19, 2053-2061. [CrossRef]

44. Tanner, J.E. Use of the stimulated echo in NMR diffusion studies. J. Chem Phys. 1970, 52, 2523-2526. [CrossRef]

45. Simari, C.; Potsi, G.; Policicchio, A.; Perrotta, I.; Nicotera, I. Clay-Carbon Nanotubes Hybrid Materials for Nanocomposite Membranes: Advantages of Branched Structure for Proton Transport under Low Humidity Conditions in PEMFCs. J. Phys. Chem. C 2016, 120, 2574-2584. [CrossRef]

46. Lian, Y.; Liu, Y.; Jiang, T.; Shu, J.; Lian, H.; Cao, M. Enhanced electromechanical performance of graphite oxide-nafion nanocomposite actuator. J. Phys. Chem. C 2010, 114, 9659-9663. [CrossRef]

47. Burgess, R.; Buono, C.; Davies, P.R.; Davies, R.J.; Legge, T.; Lai, A.; Lewis, R.; Morgan, D.J.; Robinson, N.; Willock, D.J. The functionalisation of graphite surfaces with nitric acid: Identification of functional groups and their effects on gold deposition. J. Catal. 2015, 323, 10-18. [CrossRef]

48. Shen, B.S.; Feng, W.J.; Lang, J.W.; Wang, R.T.; Tai, Z.X.; Yan, X. Bin Nitric acid modification of graphene nanosheets prepared by arc-discharge method and their enhanced electrochemical properties. Wuli Huaxue Xuebao Acta Phys. Chim. Sin. 2012, 28, 1726-1732.

49. Carlucci, C.; Scremin, B.F.; Sibillano, T.; Giannini, C.; Filippo, E.; Perulli, P.; Capodilupo, A.L.; Corrente, G.A.; Ciccarella, G. Microwave-assisted synthesis of boron-modified TiO2 nanocrystals. Inorganics 2014, 2, $264-277$. [CrossRef]

50. Kim, N.H.; Kuila, T.; Lee, J.H. Simultaneous reduction, functionalization and stitching of graphene oxide with ethylenediamine for composites application. J. Mater. Chem. A 2013, 1, 1349-1358. [CrossRef]

51. Zhang, H.; Wang, X.; Li, N.; Xia, J.; Meng, Q.; Ding, J.; Lu, J. Synthesis and characterization of TiO2/graphene oxide nanocomposites for photoreduction of heavy metal ions in reverse osmosis concentrate. RSC Adv. 2018, 8, 34241-34251. [CrossRef]

52. Tang, W.W.; Zeng, G.M.; Gong, J.L.; Liang, J.; Xu, P.; Zhang, C.; Huang, B. Bin Impact of humic/fulvic acid on the removal of heavy metals from aqueous solutions using nanomaterials: A review. Sci. Total Environ. 2014, 468-469, 1014-1027. [CrossRef] [PubMed]

53. Fu, J.; Kyzas, G.Z.; Cai, Z.; Deliyanni, E.A.; Liu, W.; Zhao, D. Photocatalytic degradation of phenanthrene by graphite oxide- $\mathrm{TiO}_{2}-\mathrm{Sr}(\mathrm{OH})_{2} / \mathrm{SrCO}_{3}$ nanocomposite under solar irradiation: Effects of water quality parameters and predictive modeling. Chem. Eng. J. 2018, 335, 290-300. [CrossRef] 
54. Boutsika, L.G.; Enotiadis, A.; Nicotera, I.; Simari, C.; Charalambopoulou, G.; Giannelis, E.P.; Steriotis, T. Nafion ${ }^{\circledR}$ nanocomposite membranes with enhanced properties at high temperature and low humidity environments. Int. J. Hydrogen Energy 2016, 41, 22406-22414. [CrossRef]

55. Enotiadis, A.; Boutsika, L.G.; Spyrou, K.; Simari, C.; Nicotera, I. A facile approach to fabricating organosilica layered material with sulfonic groups as an efficient filler for polymer electrolyte nanocomposites. New J. Chem. 2017, 41, 9489-9496. [CrossRef]

56. Nicotera, I.; Simari, C.; Boutsika, L.G.; Coppola, L.; Spyrou, K.; Enotiadis, A. NMR investigation on nanocomposite membranes based on organosilica layered materials bearing different functional groups for PEMFCs. Int. J. Hydrogen Energy 2017, 42, 27940-27949. [CrossRef]

57. Cozzi, D.; De Bonis, C.; D’Epifanio, A.; Mecheri, B.; Tavares, A.C.; Licoccia, S. Organically functionalized titanium oxide/Nafion composite proton exchange membranes for fuel cells applications. J. Power Sources 2014, 248, 1127-1132. [CrossRef]

58. Kariduraganavar, M.Y.; Kittur, A.A.; Kulkarni, S.S. Ion Exchange Membranes: Preparation, Properties, and Applications; Springer: Dordrecht, The Netherlands, 2012; ISBN 9789400717008.

59. Cossari, P.; Simari, C.; Cannavale, A.; Gigli, G.; Nicotera, I. Advanced processing and characterization of Nafion electrolyte films for solid-state electrochromic devices fabricated at room temperature on single substrate. Solid State Ion. 2018, 317, 46-52. [CrossRef]

60. Suarez, S.; Greenbaum, S. Nuclear magnetic resonance of polymer electrolyte membrane fuel cells. Chem. Rec. 2010, 10, 377-393. [CrossRef]

61. Vasile, N.S.; Monteverde Videla, A.H.A.; Simari, C.; Nicotera, I.; Specchia, S. Influence of membrane-type and flow field design on methanol crossover on a single-cell DMFC: An experimental and multi-physics modeling study. Int. J. Hydrogen Energy 2017, 42, 27995-28010. [CrossRef]

62. Feng, K.; Tang, B.; Wu, P. Sulfonated graphene oxide-silica for highly selective Nafion-based proton exchange membranes. J. Mater. Chem. A 2014, 2, 16083-16092. [CrossRef]

63. Rossi, C.O.; Caputo, P.; De Luca, G.; Maiuolo, L.; Eskandarsefat, S.; Sangiorgi, C. 1H-NMR spectroscopy: A possible approach to advanced bitumen characterization for industrial and paving applications. Appl. Sci. 2018, 8, 229. [CrossRef]

64. Simari, C.; Baglio, V.; Lo Vecchio, C.; Aricò, A.S.; Agostino, R.G.; Coppola, L.; Oliviero Rossi, C.; Nicotera, I. Reduced methanol crossover and enhanced proton transport in nanocomposite membranes based on clay-CNTs hybrid materials for direct methanol fuel cells. Ionics 2017, 23, 2113-2123. [CrossRef]

65. Li, G.H.; Lee, C.H.; Lee, Y.M.; Cho, C.G. Preparation of poly(vinyl phosphate-b-styrene) copolymers and its blend with PPO as proton exchange membrane for DMFC applications. Solid State Ion. 2006, 177, 1083-1090. [CrossRef]

(C) 2020 by the authors. Licensee MDPI, Basel, Switzerland. This article is an open access article distributed under the terms and conditions of the Creative Commons Attribution (CC BY) license (http://creativecommons.org/licenses/by/4.0/). 